\title{
Assessment of urban aerosol pollution over the Moscow megacity by the MAIAC aerosol product
}

\author{
Ekaterina Y. Zhdanova ${ }^{1}$, Natalia Y. Chubarova ${ }^{1}$, and Alexei I. Lyapustin ${ }^{2}$ \\ ${ }^{1}$ Department of Meteorology and Climatology, Faculty of Geography, Lomonosov Moscow State University, \\ Moscow, 119991, Russia \\ ${ }^{2}$ Laboratory for Atmospheres, NASA Goddard Space Flight Center, Greenbelt, Maryland, USA
}

Correspondence: Ekaterina Y. Zhdanova (ekaterinazhdanova214@gmail.com)

Received: 28 August 2019 - Discussion started: 8 October 2019

Revised: 29 December 2019 - Accepted: 7 January 2020 - Published: 21 February 2020

\begin{abstract}
We estimated the distribution of aerosol optical thickness (AOT) with a spatial resolution of $1 \mathrm{~km}$ over the Moscow megacity using the MAIAC aerosol product based on MODIS satellite data (Lyapustin et al., 2018) for the warm period of the year (May-September, 2001-2017). AERONET (Aerosol Robotic Network)-based validation of satellite estimates near the city centre at Moscow_MSU_MO and over the Moscow suburbs at Zvenigorod revealed that MAIAC AOT at $0.47 \mu \mathrm{m}$ is in agreement with AERONET AOT though underestimated by $0.05-0.1$ for AOT $<1$ and overestimated for smoke conditions with AOT $>1$. The MAIAC AOT biases were almost the same for the Moscow_MSU_MO and Zvenigorod AERONET sites, which indicated that the MAIAC algorithm effectively removed the effect of the bright urban surface in the city centre. For the ground-based measurements, the difference between annual median AOT at Moscow_MO_MSU and Zvenigorod $(\triangle \mathrm{AOT})$ varied within -0.002 to +0.03 , with statistically significant positive bias for most years, and an average $\triangle \mathrm{AOT}$ was about 0.02 . According to the MAIAC dataset, the $\triangle$ AOT varied within \pm 0.01 and was not statistically significant. The $\triangle$ AOT started decreasing recently due to intensive urban development of the territory around Zvenigorod and the decrease in pollutant emissions in Moscow, which is mainly caused by the environmental regulations. According to the MAIAC dataset, the most pronounced spatial AOT differences over the territory of Moscow were observed at the $5 \%$ quantile level, where they reached $0.05-0.06$ over several locations and could be attributed to the stationary sources of aerosol pollution, for example, large areas of construction sites, aerosol pollution from roads and highways, or
\end{abstract}

agriculture activities. The differences between the maximum and the mean AOT for different quantiles, except the $95 \%$ quantile, within the Moscow region, were about 0.02-0.04, which could be attributed to the local aerosol sources. The application of the MAIAC algorithm over the whole Moscow region has revealed a decreasing AOT trend over the centre of Moscow and an increasing trend over the "New" Moscow territory which experienced an intensive build-up and agricultural development.

\section{Introduction}

Atmospheric aerosols are the suspended particulate components of the atmosphere, which are produced directly from the emissions of particulate matter of different origins and generated from gaseous precursors. The variety of chemical and physical processes of aerosol formation provides a large diversity of their microphysical and optical properties. A significant variation of aerosol properties has been observed in the industrial urban areas. Anthropogenic aerosols affect the temperature profile, play an important role as cloud condensation nuclei, and impact the hydrologic cycle through changes in cloud cover, cloud properties, and precipitation (Kaufman et al., 2002; Kaufman, 2006).

One of the key aerosol optical characteristics is the aerosol optical thickness (AOT), whose spatial and temporal variations have been studied using satellite and ground-based data in numerous papers (Koelemeijer et al., 2006; Schaap et al., 2008; Chubarova, 2009; Bovchaliuk et al., 2013; Putaud et al., 2014; Chubarova et al., 2016). Over Europe, a perma- 
nently elevated aerosol loading was observed over several industrial regions, with particularly high values found over the Netherlands, Belgium, the Ruhr area, the Po Valley, northern Germany and the former East Germany, Poland, and parts of central European countries. Elevated aerosol loading usually correlates with suspended particulate matter associated with the poor air quality (Wang and Christopher, 2003; Hoff and Christopher, 2009; Chudnovsky et al., 2012; van Donkelaar et al., 2015). Recently a high $1 \mathrm{~km}$ resolution aerosol MAIAC satellite product has been used for estimating relationships between AOT and particulate matter (A. Chudnovsky et al., 2013; Hu et al., 2014; Kloog et al., 2015; Xiao et al., 2017; Beloconi et al., 2018; Liang et al., 2018; Han et al., 2018).

Large cities with their high road density and industrial enterprises are the source of aerosol pollution, which includes black carbon, sulfate, nitrate, and ammonium aerosol components as well as primary and secondary organic aerosols (POA and SOA) (IPCC, 2013), and the urban aerosol is dominated by the fine-mode particles (Kaufman et al., 2005).

Several recent studies reported an analysis of AOT based on ground-based and satellite data over the Moscow (Chubarova et al., 2011b; Kislov, 2017), Warsaw (Zavadzka et al., 2013), and Córdoba (central Argentina) (Della Ceca et al., 2018) urban areas.

Previously, the urban aerosol pollution in Moscow has been studied using concurrent observations by the AERONET Cimel sun photometers located in the Moscow city and in the suburbs (Zvenigorod). This study revealed an average AOT at $0.5 \mu \mathrm{m}$ of $\sim 0.19$, of which 0.02 was apportioned to the urban sources and a tendency of lower singlescattering albedo (higher absorption) in Moscow (Chubarova et al., 2011b). The difference between AOT in the city of Warsaw and suburban conditions of Belsk was estimated as 0.02 (at $0.5 \mu \mathrm{m}$ ) based on sun photometers' data (Zawadzka et al., 2013). However, the use of only two contrasting ground-based sites does not allow assessment of the detailed spatial distribution of AOT and estimation of an integrated urban aerosol loading even at high quality of the AOT measurements. This task can be solved by using high-quality satellite AOT retrievals.

The analysis of the results obtained from the Visible Infrared Imaging Spectrometer (VIIRS) (Jackson et al., 2013) showed that the central part of the city of Moscow has a significantly higher AOT at $0.55 \mu \mathrm{m}$ (by about 0.1 ) than that in the suburbs (Zhdanova and Chubarova, 2018). Such a significant difference, as discussed in this paper, probably originated from the uncertainty in evaluation of the urban surface reflectance in the VIIRS aerosol algorithm (Liu et al., 2014). The assessment of the aerosol pollution in Moscow using the mid-visible range AOT from the MODIS data (collection 5.1) with a $1^{\circ} \times 1^{\circ}$ spatial resolution during the warm period of 2000-2013 showed that the difference in AOT due to urban effects can reach up to 0.08 if compared to AOT obtained over the green areas to the north of $58^{\circ} \mathrm{N}$ or to the south of $53^{\circ} \mathrm{N}$ (Kislov, 2017). However, the spatial resolution and the uncertainties of the AOT retrievals used in this study did not allow determination of the detailed spatial features of AOT distribution. The MAIAC aerosol product (Lyapustin et al., 2018), based on MODIS data, has some advantages over the standard MODIS algorithms: it overcomes empirical assumptions related to surface reflectance and provides $\mathrm{AOT}$ at high $1 \mathrm{~km}$ spatial resolution. MAIAC uses the minimum reflectance method, implemented dynamically, to separate atmospheric and surface contributions. The sliding window technique, accumulating a time series of data for up to $16 \mathrm{~d}$, provides a necessary surface characterization via dynamic retrieval of the spectral bidirectional reflectance distribution function (BRDF) (Lyapustin et al., 2018). A good knowledge of surface BRDF allows MAIAC to minimize effects of both surface brightness and view geometry on MAIAC AOT as compared to the standard MODIS Dark Target (DT) and Deep Blue (DB) products (e.g. Mhawish et al., 2019; Jethva et al., 2019).

Thus, the objective of this paper is to verify the MAIAC aerosol retrievals against the ground-based AERONET measurements over the Moscow area (for the urban and suburban sites) and to evaluate the temporal trends and spatial features of the urban aerosol pollution over the Moscow megacity for the time period from 2001 to 2017.

\section{The study area, datasets, and methodology}

\subsection{The study area}

The Moscow megacity $\left(55^{\circ} 45^{\prime} \mathrm{N}, 37^{\circ} 37^{\prime} \mathrm{E}\right)$ is one of the largest urban agglomerations in the world, with a population of 12.6 million according to the Federal Statistics Service (on 1 January 2019) with industrial enterprises and technologies in the fields of mechanical engineering and metalworking, energy and petrol chemistry, light and food industries, construction materials, and an intensive residential development (Kulbachevski, 2018). In 2012, the Moscow megacity expanded mostly to the south-west to include a "New" Moscow region. As a result, its territory has increased from 1091 to $2511 \mathrm{~km}^{2}$ (https://www.mos.ru/en/, last access: 1 September 2019). The study domain is shown in Fig. 1. The Moscow city boundaries, its administrative districts, and a satellite image of the Moscow region are shown in Fig. 1.

\subsection{MAIAC data}

A new MODIS satellite product - MCD19A2 Collection 6 (MAIAC aerosol product) with $1 \mathrm{~km}$ spatial resolution - was used to estimate the spatial-temporal distribution of AOT over the Moscow region (https://search.earthdata.nasa.gov/ search, last access: 1 September 2019). The MCD19A2 product provides a suite of atmospheric parameters and view geometry, including column water vapour, AOT at 0.47 and $0.55 \mu \mathrm{m}$, AOT uncertainty, fine-mode fraction over water, 
(a) Domain and AERONET stations

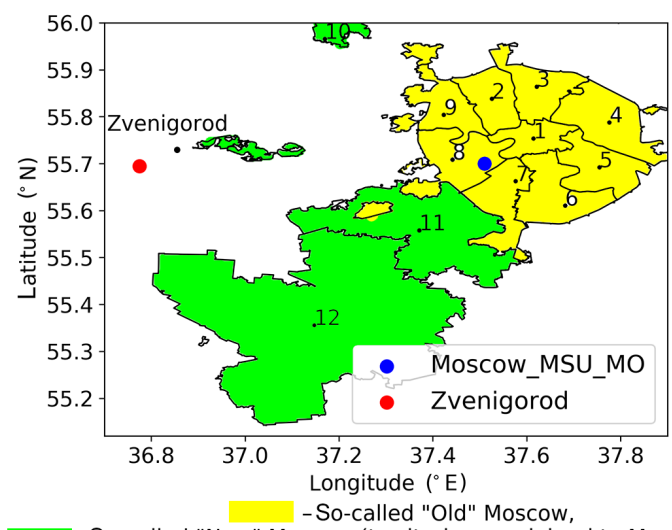

-So-called "New" Moscow (territories are joined to Moscow in 2012)

(b)
1 Central Administrative Discrict

2 Northern Administrative Discrict

3 Northeast Administrative Discrict

4 Eastern Administrative Discrict

5 Southeast Administrative Discrict

6 Southern Administrative Discrict

7 Southwest Administrative Discrict

8 Western Administrative Discrict

9 Northwest Administrative Discrict

10 Zelenograd Administrative Discrict

11 Novomoskovsk Administrative Discrict

12 Troitsk Administrative Discrict

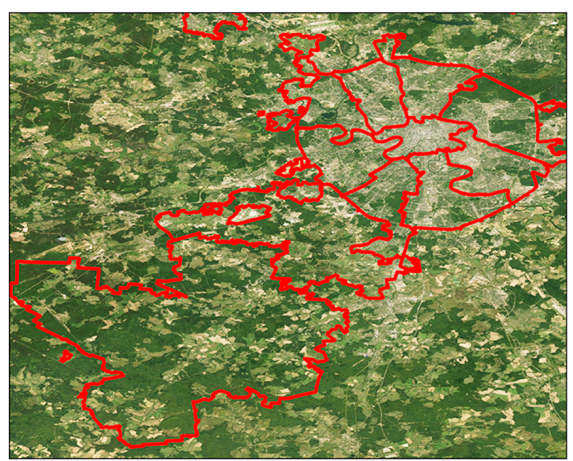

Figure 1. Study domain and locations of AERONET sites. (a) "Old" and "New" Moscow, administrative districts. (b) Satellite image (ArcGIS World Imagery: https://arcg.is/4zubf, last access: 20 December 2019).

smoke injection height (metres above ground), AOT QA (quality assurance), AOT model at $1 \mathrm{~km}$, and a view geometry suite at $5 \mathrm{~km}$ (cosine of solar zenith angle, cosine of view zenith angle, relative azimuth angle, scattering angle, and glint angle). Each parameter within each MCD19A2 Hierarchical Data Format 4 (HDF4) file contains a third dimension that represents the number of orbit overpasses. We used the data for the warm snow-free time period from May to September over the 2001-2017 years. The geographical location of the Moscow region corresponds to MODIS granule h20v03. The MAIAC algorithm retrieves AOT at $0.47 \mu \mathrm{m}$ and provides an additional value at the standard wavelength $0.55 \mu \mathrm{m}$ calculated according to the aerosol model used. MAIAC uses eight different regional background aerosol models tuned to the AERONET (Aerosol Robotic Network; Holben et al., 1998) climatology. Each geographical location has one predefined aerosol model. Aerosol model number 1 is used for the Moscow region. The MAIAC algorithm also detects absorbing dust and smoke aerosols and provides a dust/smoke mask in the QA. The smoke test relies on a relative increase in aerosol absorption at MODIS wavelength $412 \mathrm{~nm}$ compared to $470-670 \mathrm{~nm}$ owing to multiple scattering and enhanced absorption by organic carbon released during biomass burning combustion (Lyapustin et al., 2012). A detailed description of the MAIAC aerosol algorithm can be found in Lyapustin et al. (2018). Only AOT values with the highest quality were used in the presented analysis (QA.QA_AOT = Best_Quality).

\subsection{AERONET data}

The data from the two sites equipped with the Cimel sun/sky photometers of the AERONET project (Holben et al., 1998) were used for validating the satellite AOT retrievals as well as for determining the features of the AOT temporalspatial distribution over the territory of the Moscow megacity. They included the measurements of the Observatory of Moscow State University (Moscow_MSU_MO site; $55.70695^{\circ} \mathrm{N}, 37.52202^{\circ} \mathrm{E}$ ) over the $2002-2017$ period and Zvenigorod Scientific Station of the Institute of Atmospheric Physics, Russian Academy of Sciences (Zvenigorod site; $55.695^{\circ} \mathrm{N}, 36.775^{\circ} \mathrm{E}$ ) over the $2006-2017$ period. The first site is located within the city, at a distance of about $8 \mathrm{~km}$ from the city centre, and the second is the upwind suburban area about $50 \mathrm{~km}$ west from the city centre. The AERONET measurements at level 2, version 3 (Giles et al., 2019) were used with the additional cloud screening us- 
ing ground-based visual cloud observations at the Meteorological Observatory of Moscow State University, as described in Chubarova et al. (2016). Long-term measurements at the Moscow_MSU_MO have revealed noticeable seasonal changes in AOT with a maximum in April and July, with a median AOT at $0.5 \mu \mathrm{m}$ of about 0.22 and a minimum in December and January with AOT at $0.5 \mu \mathrm{m}$ of 0.07 (Chubarova et al., 2011a, 2016). However, in this study we focused on the snow-free period (May-September); during this period of the year AOT variations are not large $(\sim 0.15-0.21)$. Additionally, we used AERONET estimates of fine-mode fraction (O'Neill et al., 2003). The locations of the AERONET sites are shown in Fig. 1.

\subsection{EMEP data}

In addition, we used the EMEP (European Monitoring and Evaluation Programme) grid archive (http://www.ceip.at/ new_emep-grid/01_grid_data, last access: 1 August 2019; EMEP/CEIP, 2019) to assess the spatial-temporal distribution of aerosol precursor gas emissions to explain the spatial features of the AOT distribution. We analysed the main precursor gases $\mathrm{NO}_{x}, \mathrm{SO}_{x}, \mathrm{NMVOC}$, and $\mathrm{NH}_{3}$ along with particulate matter concentrations $\left(\mathrm{PM}_{2.5}\right.$ and $\left.\mathrm{PM}_{10}\right)$.

\section{Results}

\subsection{Validation of satellite AOT retrievals against ground-based data}

The MAIAC aerosol algorithm was successfully validated over various geographic regions: over bright desert surfaces (Sever et al., 2017), over South Asia (India) (Mhawish et al., 2019), over mountainous areas (Emili et al., 2011), across South America (Martins et al., 2017), and over North America (Jethva et al., 2019). Mhawish et al. (2019) gave a detailed comparison of MAIAC data with standard MODIS algorithms and ground-based data and studied the accuracy of the product as a function of the sensor (MODIS on Terra or Aqua), the underlying surface, the aerosol model, and scanning geometry. According to Mhawish et al. (2019), the MAIAC AOT error is about $15 \%$. At high AOT, MAIAC underestimates AOT, especially in the MODIS Aqua record (Mhawish et al., 2019). However, on average, the AOT MAIAC data are characterized by smaller errors compared to the two operational MODIS algorithms: Dark Target (Levy et al., 2013) and Deep Blue (Hsu et al., 2013).

We averaged AERONET data to $1 \mathrm{~h}$ resolution and calculated AOT at $0.47 \mu \mathrm{m}$ from available AERONET AOT at $0.44 \mu \mathrm{m}$ and an Ångstrom exponent $(0.44-0.87 \mu \mathrm{m})$ in this study. MAIAC AOT data were spatially averaged with a $5 \mathrm{~km}$ radius circle centred at the Moscow_MSU_MO and Zvenigorod sites and also averaged within $1 \mathrm{~h}$ to have robust estimates. Correlations are plotted separately for the Terra and Aqua datasets and together for the data from the two satellites in the $1 \mathrm{~h}$ intervals (Fig. 2). As can be seen in Fig. 2, the satellite AOT at $0.47 \mu \mathrm{m}$ retrievals for Moscow_MO_MSU and Zvenigorod is underestimated by about -0.05 for the values less than 1 and overestimated in conditions of high aerosol loading in Moscow. However, the correlation between the AOT MAIAC retrievals and AERONET data is high. Slopes of regression lines are higher at the Moscow_MO_MSU site than that at Zvenigorod, since at the Zvenigorod site high aerosol loading due to forest and peatbog fires has not been included in the sample.

The overestimation of the AOT MAIAC occurs in cases of forest fires, when the MAIAC algorithm detects smoke. This is clearly seen in Fig. 3, where the cases of detected smoke are shown by an orange colour. Overall, this error is in contrast to the typical biomass burning conditions when the MAIAC algorithm usually underestimates AOT (e.g. see Lyapustin et al., 2018). The underestimation is caused by the fact that the MAIAC C6 algorithm keeps using the same background model in cases of detected smoke, which usually has higher absorption for fresh smoke aerosol (Dubovik et al., 2002). By contrast, the Moscow smoke of 2010 was largely a result of smouldering peat fires producing larger particle size and lower absorption (Chubarova et al., 2012; Sayer et al., 2014), the combination of which led to the AOT overestimation.

Statistical estimates (RMSE - root mean square error, MAE - mean absolute error, BIAS - mean error) of the quality of the AOT at $0.47 \mu \mathrm{m}$ retrievals relative to the groundbased AERONET data are presented in Table 1. It is worth noting that the errors of the MAIAC AOT are similar to both the Moscow_MSU_MO and Zvenigorod sites, which indicates that the bias is model-related, while the contribution of the bright urban underlying surface is effectively taken into account in the MAIAC algorithm.

\subsection{Temporal AOT changes in Moscow according to ground-based and satellite data}

We studied temporal AOT changes using MAIAC AOT retrievals and AERONET long-term measurements collocated in time over the Moscow_MSU_MO site during a warm May-September period. Figure 4a shows the time series of AOT at $0.55 \mu \mathrm{m}$ built for all available Moscow_MSU_MO AERONET and MAIAC data. One can see a satisfactory agreement between the satellite and ground-based observations, with the exception of years 2002 and 2010. The highest AOT values were observed in years 2010 and 2002 due to the effects of smoke aerosols from peat and forest fires in the Moscow region (Chubarova et al., 2011a). In 2016 the smoke aerosol advection was also observed from the Siberia area (Sitnov et al., 2017), providing an intermediate AOT maximum. Figure $4 \mathrm{~b}$ shows year-to-year variability of AOT at $0.55 \mu \mathrm{m}$ only for matching within $1 \mathrm{~h}$ Moscow_MSU_MO AERONET and MAIAC data and for the cases when the MAIAC regional background aerosol model has been ap- 
(a) MOSCOW_MO_MSU

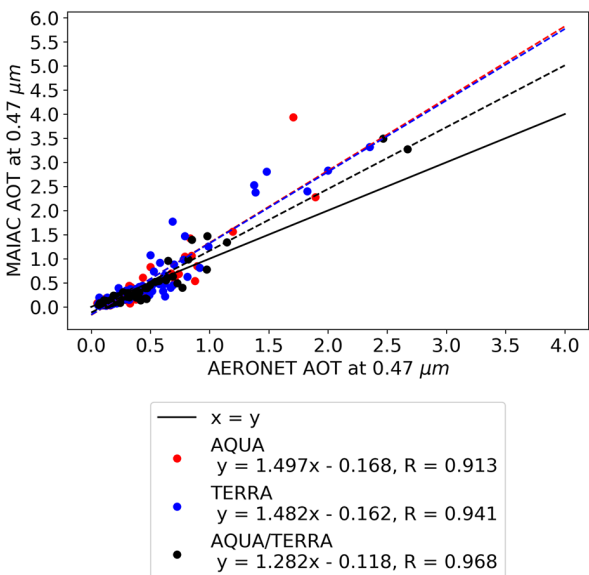

(b) ZVENIGOROD

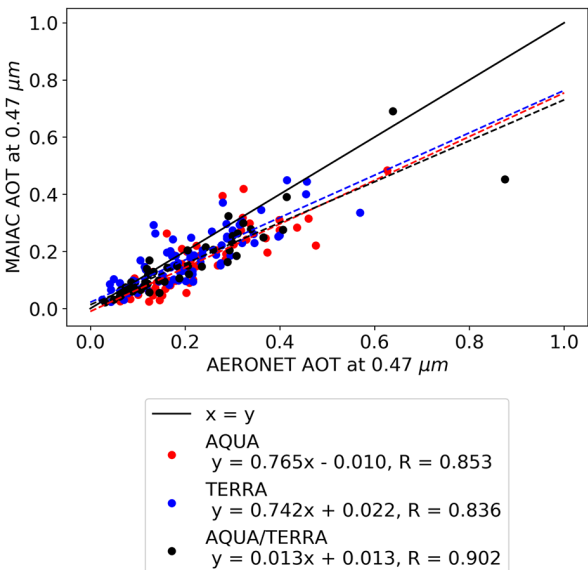

Figure 2. Correlations between MAIAC AOT at $0.47 \mu \mathrm{m}$ and AERONET AOT at $0.47 \mu \mathrm{m}$ for the Moscow_MSU_MO and Zvenigorod AERONET sites for Terra, Aqua, and their joint overpasses within $1 \mathrm{~h}$ (Aqua/Terra). Comment: the absence of high AOT values at the Zvenigorod site is explained by technical problems with the instrument and the absence of the AERONET data at level 2, version 3 in 2010 , when intensive forest fires took place.
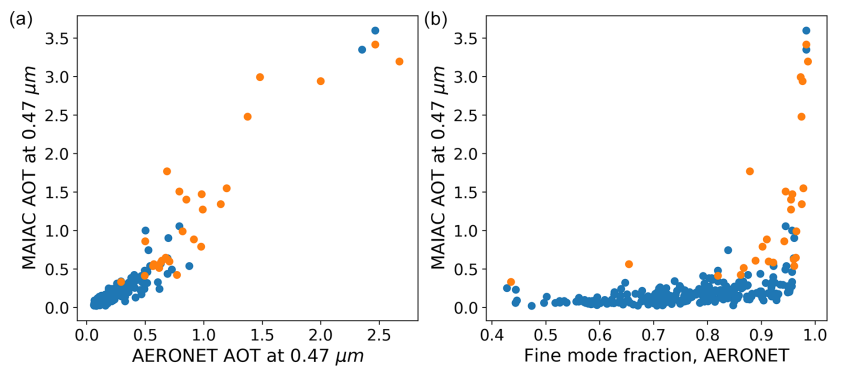

Figure 3. MAIAC AOT at $0.47 \mu \mathrm{m}$ against AERONET AOT (a) and MAIAC AOT at $0.47 \mu \mathrm{m}$ against fine-mode fraction AOT AERONET (b) according to the regional MAIAC aerosol model (blue colour) and in cases of smoke detection (orange colour). Moscow, 2001-2017.

plied. One can see a better agreement between the MAIAC AOT and the corresponding AERONET AOT data in year-to-year variations. There is a clearly seen decrease in AOT during the last years according to both the MAIAC (when the regional model was used) and AERONET data. The yearly means difference between AERONET and MAIAC data (AOT MAIAC - AOT AERONET) is -0.03 for all the matching data (blue and red lines in Fig. 4b) and -0.05 for the matching data with MAIAC regional aerosol model estimates (blue and orange lines in Fig. 4b). Figure 4c presents the AOT variations only for the cases of the MAIAC smoke detection. It is seen that the AOT MAIAC overestimation takes place only for the cases with high AOT $>1$.

Thus, the MAIAC AOT algorithm reproduces the absolute AOT values and the long-term AOT decrease in Moscow for the regional background aerosol model, while in the case of smoke aerosol detection there is a significant overestimation
Table 1. Statistical estimates of the uncertainties in AOT MAIAC retrievals for the Terra and Aqua data separately, for the Terra and Aqua measurements within $1 \mathrm{~h}$ (Aqua/Terra), and together for the data from the two satellites (Terra and Aqua) against ground-based AERONET data at the MOSCOW_MO_MSU (2001-2017) and ZVENIGOROD (2006-2017) sites.

\begin{tabular}{|c|c|c|c|c|}
\hline & Terra & Aqua & Aqua/Terra & Terra and Aqua \\
\hline \multicolumn{5}{|c|}{ MOSCOW_MSU_MO, all AOT } \\
\hline RMSE & 0.24 & 0.23 & 0.17 & 0.22 \\
\hline MAE & 0.12 & 0.1 & 0.09 & 0.11 \\
\hline BIAS & 0 & -0.02 & -0.02 & -0.02 \\
\hline$N$ & 181 & 130 & 99 & 410 \\
\hline \multicolumn{5}{|c|}{ MOSCOW_MSU_MO,AOT $<1$} \\
\hline RMSE & 0.1 & 0.09 & 0.1 & 0.1 \\
\hline MAE & 0.07 & 0.07 & 0.07 & 0.07 \\
\hline BIAS & -0.05 & -0.05 & -0.05 & -0.06 \\
\hline$N$ & 171 & 124 & 94 & 389 \\
\hline \multicolumn{5}{|c|}{ ZVENIGOROD, AOT < 1} \\
\hline RMSE & 0.07 & 0.09 & 0.08 & 0.08 \\
\hline MAE & 0.05 & 0.07 & 0.05 & 0.06 \\
\hline BIAS & -0.03 & -0.06 & -0.04 & -0.04 \\
\hline$N$ & 77 & 61 & 48 & 186 \\
\hline
\end{tabular}

RMSE: root mean square error; MAE: mean absolute error; BIAS: mean error; $N$ : case number.

of the annual AOT mean. Therefore, for the further analysis of urban aerosol pollution, we used only the AOT MAIAC retrievals with its attribution to the regional background model for removing large smoke aerosol effects, which are also characterized by significant spatial inhomogeneity. 

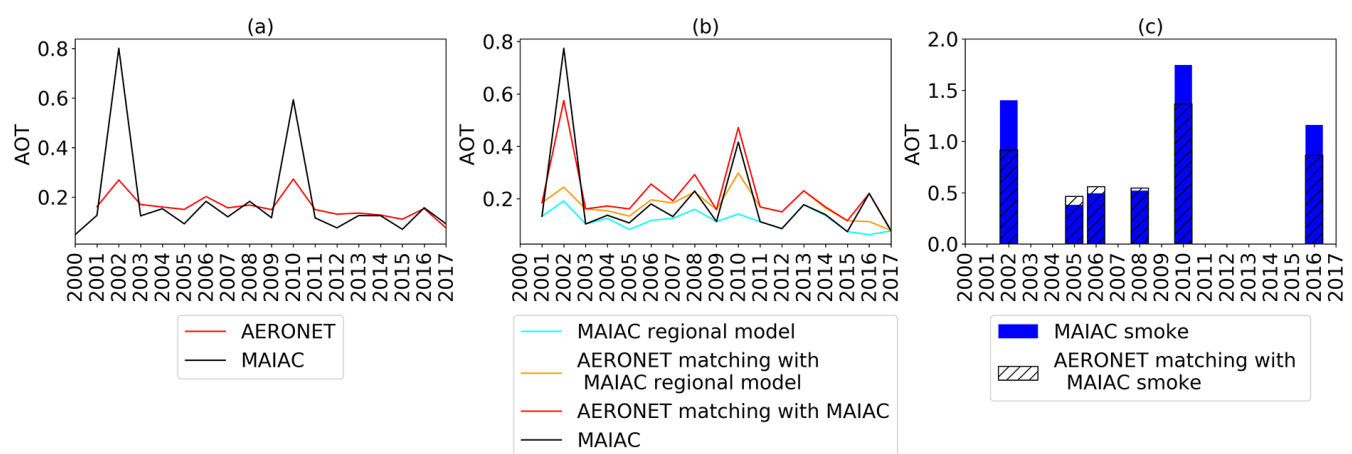

Figure 4. The year-to-year variations of AOT at $0.55 \mu \mathrm{m}$ (May-September, mean values) according to AERONET (Moscow_MSU_MO) and MAIAC data: (a) all available AERONET and MAIAC data, (b) matching AERONET and MAIAC data for all cases and for the regional aerosol model only, and (c) AOT MAIAC in cases of smoke detection and matching AERONET data.

\subsection{AOT urban effect according to ground-based and satellite measurements over the Moscow_MSU_MO and Zvenigorod AERONET sites}

Let us consider how accurately MAIAC can reproduce the urban aerosol effect, which we evaluate as the difference of AOT between Moscow_MSU_MO and Zvenigorod $\quad(\triangle \mathrm{AOT}=\mathrm{AOT}(\mathrm{MOSCOW}$ _MO_MSU $)-$ AOT(ZVENIGOROD)). It should be noted that two sites are close enough to each other, so they are influenced by the medium- and long-range transport similarly. Note that the Zvenigorod site has an upwind location. Figure 5 shows a relationship between $\triangle$ AOT from MAIAC and from hourly averaged AERONET data. The $\triangle \mathrm{AOT}$ values obtained from both ground-based and satellite data lie within the range of $-0.1 \ldots 0.1$. It should be noted that the $\triangle \mathrm{AOT}$ values between Moscow_MSU_MO and Zvenigorod based on satellite and ground-based data generally correspond to each other. The $\triangle$ AOT between the city and the suburbs can be both positive and negative: $\triangle$ AOT varies from -0.4 to 0.21 according to ground-based data and from -0.22 to 0.1 according to satellite data (see Fig. 5b).

To characterize variations in $\triangle \mathrm{AOT}$ we analysed frequency distributions according to ground-based and satellite data. In general, polar-orbiting satellites demonstrate similar daily average AOT independent of morning or afternoon orbits (Kaufman et al., 2000). However, we calculated $\Delta$ AOT separately for the Terra and Aqua datasets to evaluate possible diurnal (in the morning and noon hours) variability of $\Delta$ AOT. Frequency distributions of $\Delta$ AOT at 0.47 and $0.55 \mu \mathrm{m}$ separately for the Terra and Aqua data, and together for the data from the two satellites, are shown in Fig. 6. The highest repeatability of $\triangle \mathrm{AOT}$ is in the range of $0-0.05$. For the Aqua AOT retrievals, which are closer to noon, the predominance of positive $\triangle \mathrm{AOT}$ is more pronounced. Figure 6 also shows large negative $\triangle \mathrm{AOT}$ in the cases of Terra measurements in our sample. Overall, the $\Delta$ AOT at 0.47 values lie within the $[0,0.05]$ bin in $57 \%$ of the cases for the Aqua datasets and in $50 \%$ of the cases for the Terra datasets.

The diurnal variations of the $\triangle \mathrm{AOT}$ according to satellite and ground-based data are also shown in Fig. 7. The MAIAC $\triangle \mathrm{AOT}$ at $0.47 \mu \mathrm{m}$ are close to zero at the level of median values and do not exceed 0.01 . The inter-quantile range of the $\Delta \mathrm{AOT}$ at $0.47 \mu \mathrm{m}$ is smaller for satellite data as compared to ground-based data. Satellite and ground-based $\triangle \mathrm{AOT}$ values at $0.47 \mu \mathrm{m}$ are consistent with each other in the diurnal pattern.

To evaluate temporal $\triangle \mathrm{AOT}$ changes, we analysed variations in annual (warm period) AOT means in Moscow and Zvenigorod. The interannual variations of AOT at $0.55 \mu \mathrm{m}$ means are shown in Fig. 8 according to the AERONET and MAIAC datasets for the 2006-2017 period. For several years the $\triangle$ AOT values according to AERONET measurements are statistically significant at the $95 \%$ confidence level, reaching 0.02-0.03 (median value is 0.02 ), while the MAIAC $\triangle$ AOT values are close to zero and not statistically significant for all years. The $\triangle \mathrm{AOT}$ values according to groundbased AERONET observations are positive and higher before 2012. The confidence intervals for the MAIAC data are much larger than the confidence intervals for the AERONET data because of small numbers of satellite matchups.

We excluded AOT for years 2009, 2010, and 2013 in the datasets. The AOT at $0.55 \mu \mathrm{m}$ was significantly higher in Zvenigorod compared to Moscow in 2009, probably due to technical problems. Note that most of the Zvenigorod data during the warm period of 2009 were not included in the previous version 2 of AERONET (an email, Alexander Smirnov, personal communication, August 2019). In 2010, the AOT values were strongly affected by extremely high smoke aerosol loading (Chubarova et al., 2012), which was characterized by significant spatial heterogeneity. The data of year 2013 were excluded because of the lack of a sufficient number of MAIAC observations to obtain robust estimates.

In general, almost for all years we see a tendency of AOT decreasing in Moscow both for the AERONET datasets and 

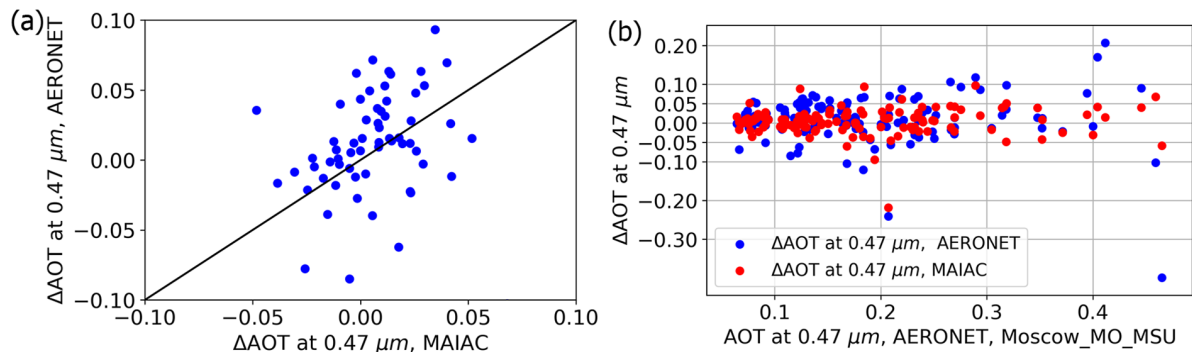

Figure 5. (a) Relationship between $\triangle \mathrm{AOT}$ at $0.47 \mu \mathrm{m}\left(\triangle \mathrm{AOT}=\mathrm{AOT}_{\mathrm{Moscow} \_\mathrm{MO} \_\mathrm{MSU}}-\mathrm{AOT}_{\mathrm{Zvenigorod}}\right)$ obtained from the satellite and ground-based data; (b) $\triangle \mathrm{AOT}$ at $0.47 \mu \mathrm{m}$ as a function of AOT at $0.47 \mu \mathrm{m}$ obtained from the Moscow_MSU_MO dataset.
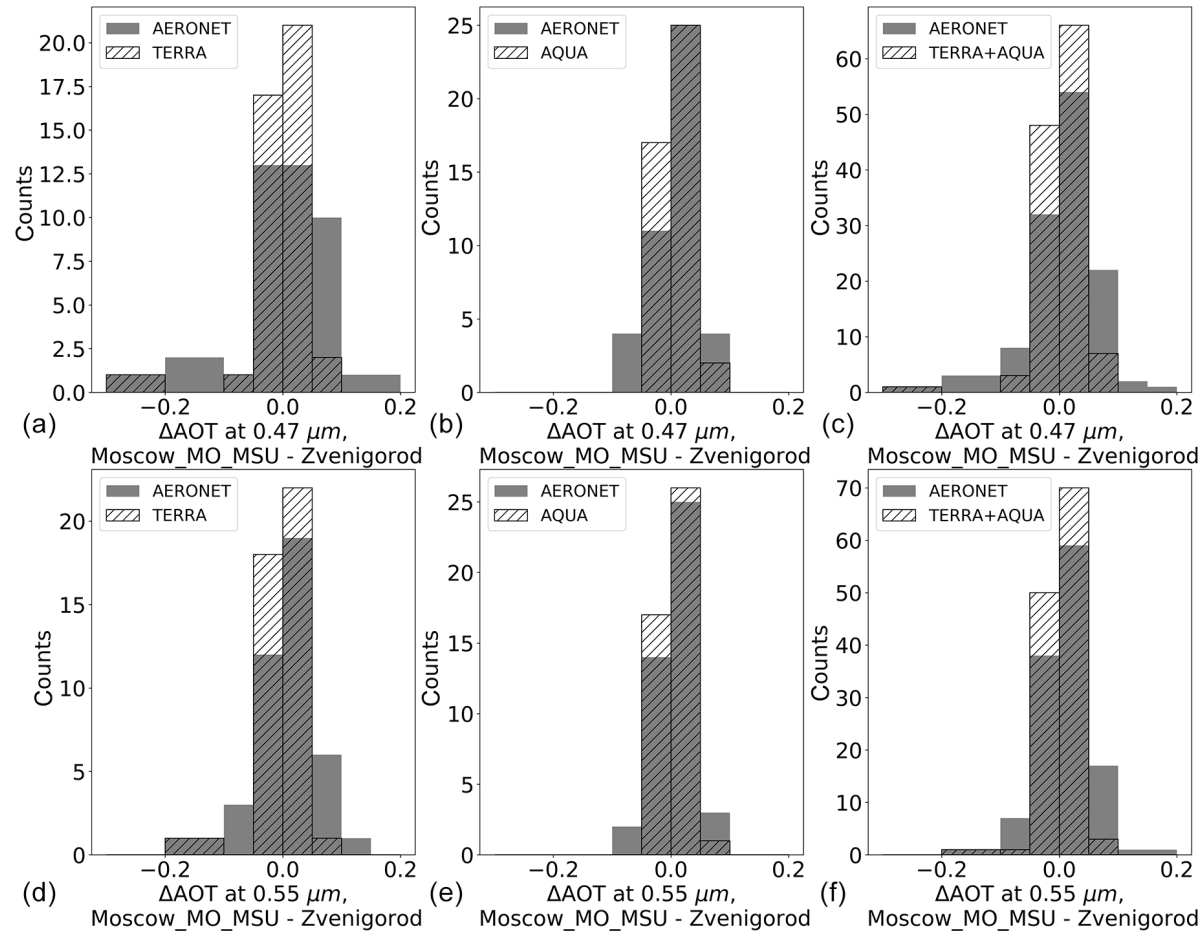

Figure 6. Frequency distribution of $\Delta \mathrm{AOT}\left(\triangle \mathrm{AOT}=\mathrm{AOT}_{\mathrm{Moscow} \_\mathrm{MO} \_\mathrm{MSU}}-\mathrm{AOT}_{\text {Zvenigorod }}\right)$ at $0.47 \mu \mathrm{m}(\mathbf{a}, \mathbf{b}, \mathbf{c})$ and $0.55 \mu \mathrm{m}(\mathbf{d}, \mathbf{e}, \mathbf{f})$ separately for the Terra (a, d) and Aqua (b, e) datasets and together for the data from the two satellites (c, f) with frequency distribution for matching ground-based AERONET data (2006-2017, without the data of 2009 because of technical problems at the Zvenigorod AERONET site). The number of satellite and ground-based matchups is 125 .

satellite retrievals. A similar but less pronounced negative trend of AOT is observed in Zvenigorod. In addition, in recent years (2013-2017), excluding the 2016 year due to the influence of AOT spatial inhomogeneity of Siberian forest fires, the $\triangle$ AOT becomes smaller and, moreover, negative (Fig. 8c). We should note that a significant increase in vehicular traffic near the Zvenigorod site, located $150 \mathrm{~m}$ away from a road, during the past 25 years has resulted in the growth of the surface aerosol air pollution level by about 23 times (Kopeikin et al., 2018), which can lead to the total AOT increase there.

\subsection{The spatial AOT distribution over the Moscow region and its change in time}

Figure 9 presents the median AOT values for the two time periods (2002-2009 and 2010-2017), which show a decrease in AOT over the territory of "Old" Moscow and an increase over the territory of "New" Moscow. This AOT decrease is consistent with the negative AOT tendency in AOT over Moscow_MSU_MO and Zvenigorod according to AERONET and MAIAC data (see the discussion above).

Spatial changes in AOT over "Old" Moscow and "New" Moscow may be explained by the emissions of urban pollutants-aerosol precursors, and, to some extent, could be 

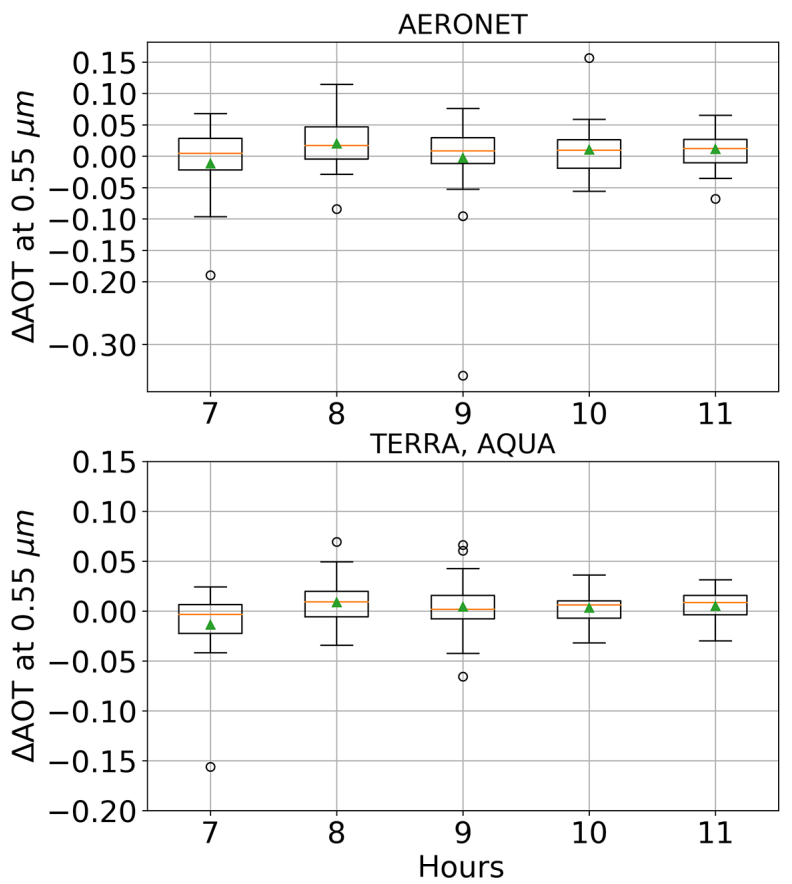

Figure 7. Daily variations of the $\Delta \mathrm{AOT}$ at $0.47 \mu \mathrm{m}(\Delta \mathrm{AOT}=$ AOT Moscow_MO_MSU - AOT $\left._{\text {Zvenigorod }}\right)$, UTC time. The median is in the centre, the box is the first (Q1) and the third (Q3) quartiles, and the whiskers are $\mathrm{Q} 3+1.5 \cdot(\mathrm{Q} 3-\mathrm{Q} 1)$ and $\mathrm{Q} 1-1.5 \cdot(\mathrm{Q} 3-$ Q1). Green triangles: means; points: outliers (2006-2017, without the data of 2009 because of technical problems at the Zvenigorod AERONET site). The number of satellite and ground-based matchups is 125 .

associated with the uncertainties in evaluation of the type of underlying surface (for example, the temporal changes in reflectance due to the urban development).

Concerning the possible effect of surface changes, we should note that the MAIAC algorithm provides a dynamic characterization of the surface reflectance properties and spectral ratios required for aerosol retrieval and should catch temporal surface changes associated with urban development (Lyapustin et al., 2018). In addition, the change in the underlying surface types was analysed using the standard MODIS MCD12C1 Collection 6 product (Majority_Land_Cover_Type_1), which has a spatial resolution of $5 \mathrm{~km}$. The analysis has showed that there was no significant increase in the urban underlying surface over the period 2001-2016. The number of grid cells occupied by the urban development increased only by $6 \%$ over the north of the "New" Moscow territory.

We have also determined the changes in emissions of aerosol precursors for the period 2011-2016 relative to the period 2003-2009 according to the EMEP grid archive (Fig. 10). $\mathrm{NO}_{x}$ emissions were characterized by a decrease of about $30 \%$ over the territory of Moscow. $\mathrm{NO}_{x}$ emissions from motor vehicles decreased over the considered ter- ritory on average by $17 \%$. The decrease in $\mathrm{SO}_{x}$ emissions was on average $14 \%$ over the territory of "Old" Moscow and, at the same time, the $\mathrm{SO}_{x}$ emissions increased over the territory of "New" Moscow by about $43 \%$. Emissions of $\mathrm{NH}_{3}$ over the territory of Moscow increased on average by $81 \%$. Emissions of non-methane volatile organic compounds (NMVOCs) over the territory of "Old" Moscow decreased by about $6 \%$, and at the same time, there was an increase in emissions of NMVOCs over the south-west of the considered domain, up to $43 \%$. There was an increase in suspended particles over the territory of "Old" Moscow $(+16 \%$ $\mathrm{PM}_{10}$ and $+6 \%$ for $\mathrm{PM}_{2.5}$ ) and much larger growth in $\mathrm{PM}$ (approximately 2-fold) over the territory of "New" Moscow. However, in recent years there has been a decrease in suspended particles relative to the level of year 2010.

The obtained results are consistent, for example, with the data in Chernogaeva et al. (2019), according to which over the past 10 years, pollutant emissions have decreased in "Old" Moscow, which is caused mainly by environmental regulations (Kulbachevski et al., 2018), and increased in the Moscow region. Thus, the higher AOT values over the territory of "New" Moscow can be explained by higher aerosol precursor emissions over this area than those over "Old" Moscow.

We also applied the quantile analysis to the spatial AOT fields obtained from the MAIAC algorithm separately for the Aqua and Terra datasets and for both of them. The quantile estimates of AOT over the territory of the Moscow region are shown in Fig. 11 and Table 2. In addition to the mentioned elevated mean AOT values over the territory of "New" Moscow, relatively high AOT at $0.47 \mu \mathrm{m} 50 \%$ quantile values are observed in the south-western and southern administrative districts of "Old" Moscow (see Fig. 1), probably due to highways and industrial enterprises (Fig. 11). The spatial changes in AOT over the territory of "Old" Moscow are about 0.03 for wavelengths 0.47 and $0.55 \mu \mathrm{m}$. One can see the most pronounced spatial differences in AOT at the $5 \%$ quantile level, where they may reach $0.05-0.06$ over several locations in some cases and can be attributed to the stationary sources of aerosol pollution over "Old" Moscow, for example, the areas of building constructions or industrial zones, which can be clearly distinguished in Fig. 12. The enhanced AOT over the territory of "New" Moscow is associated with locations of farmlands, which are used in active agricultural activity providing additional aerosol emission. We determined the locations of areas of building constructions, industrial zones, and farmlands using high-resolution satellite images (WorldView-2, IKONOS).

Table 2 presents mean and maximum values of AOT quantiles for the territories of "Old" and "New" Moscow separately for the Aqua and Terra datasets and for both of them. One can see that over local points the difference between maximum AOT and mean AOT values comprises about 0.02 0.04 for different quantiles, except the $95 \%$ quantile, which can be attributed as the local aerosol effect observed in the 

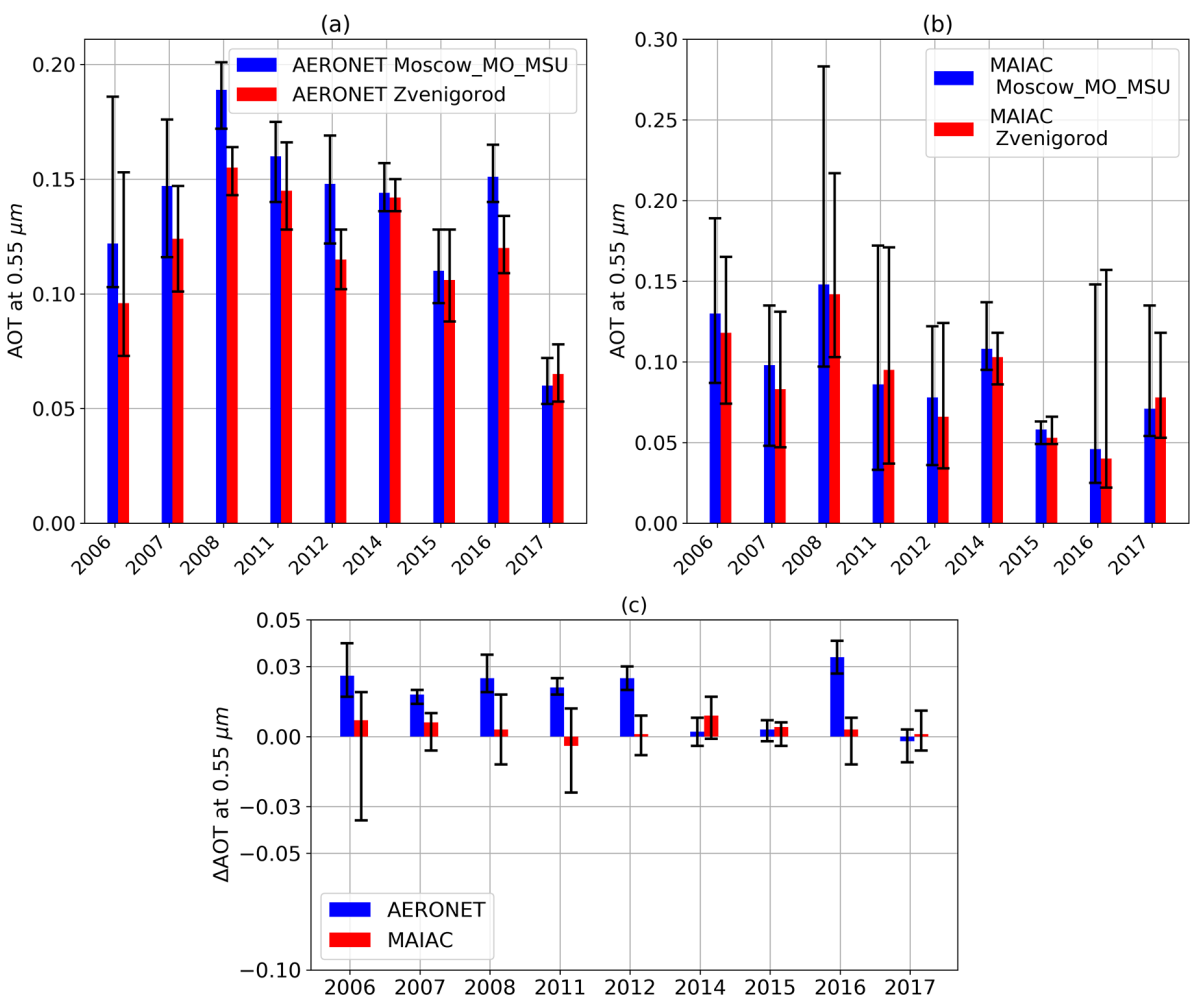

Figure 8. (a) Year-to-year variations of May-September AOT at $0.55 \mu \mathrm{m}$ medians (a) according to all matching AERONET Moscow_MSU_ MO and Zvenigorod data $(N=1492)$, (b) according to the MAIAC data $(N=264)$, and (c) $\triangle$ AOT according to matching datasets. Error bars are given at the $95 \%$ confidence level.
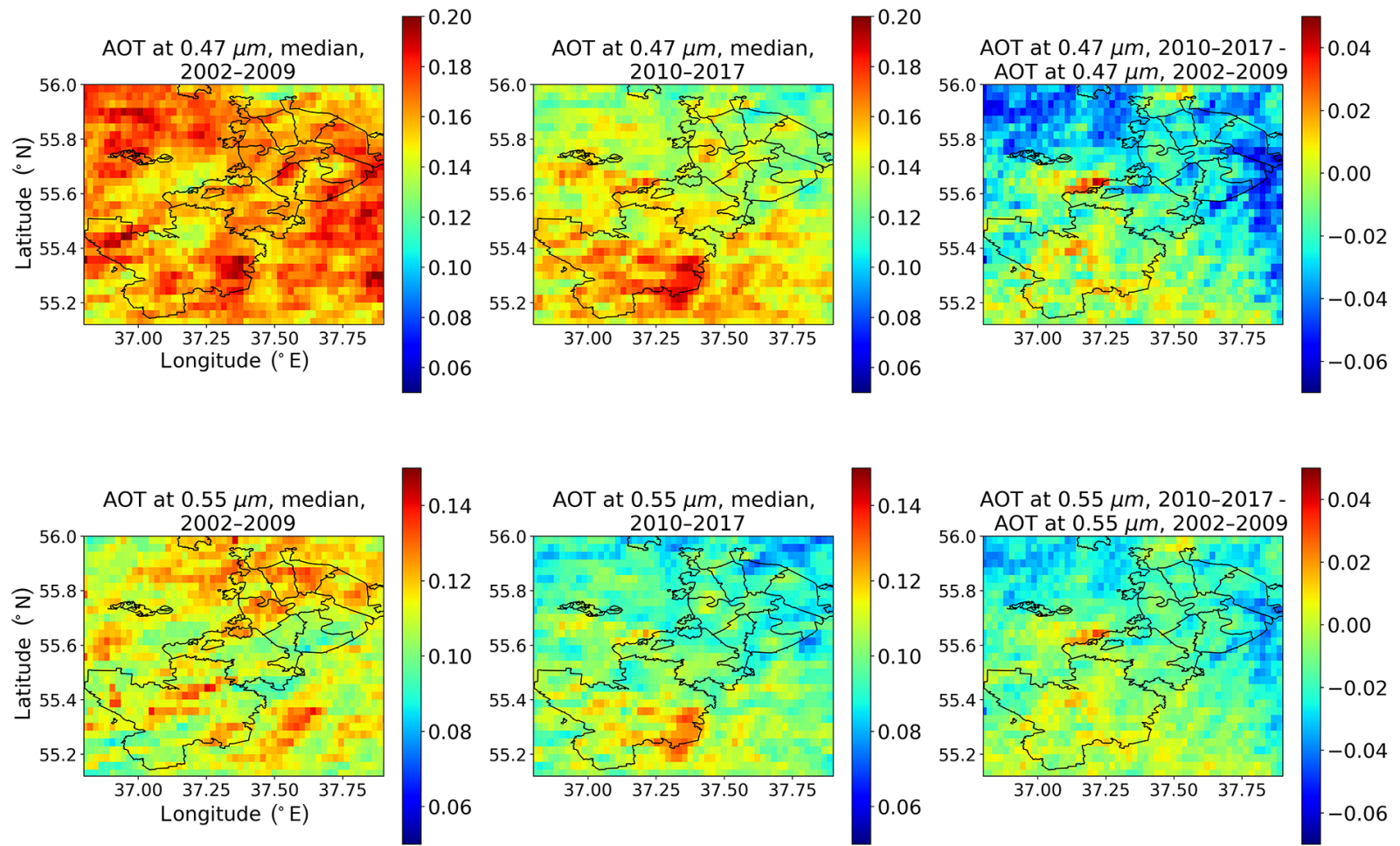

Figure 9. AOT MAIAC at $0.47 \mu \mathrm{m}$ and AOT at $0.55 \mu \mathrm{m}$ median values for the 2002-2009 and 2010-2017 periods and their differences. 

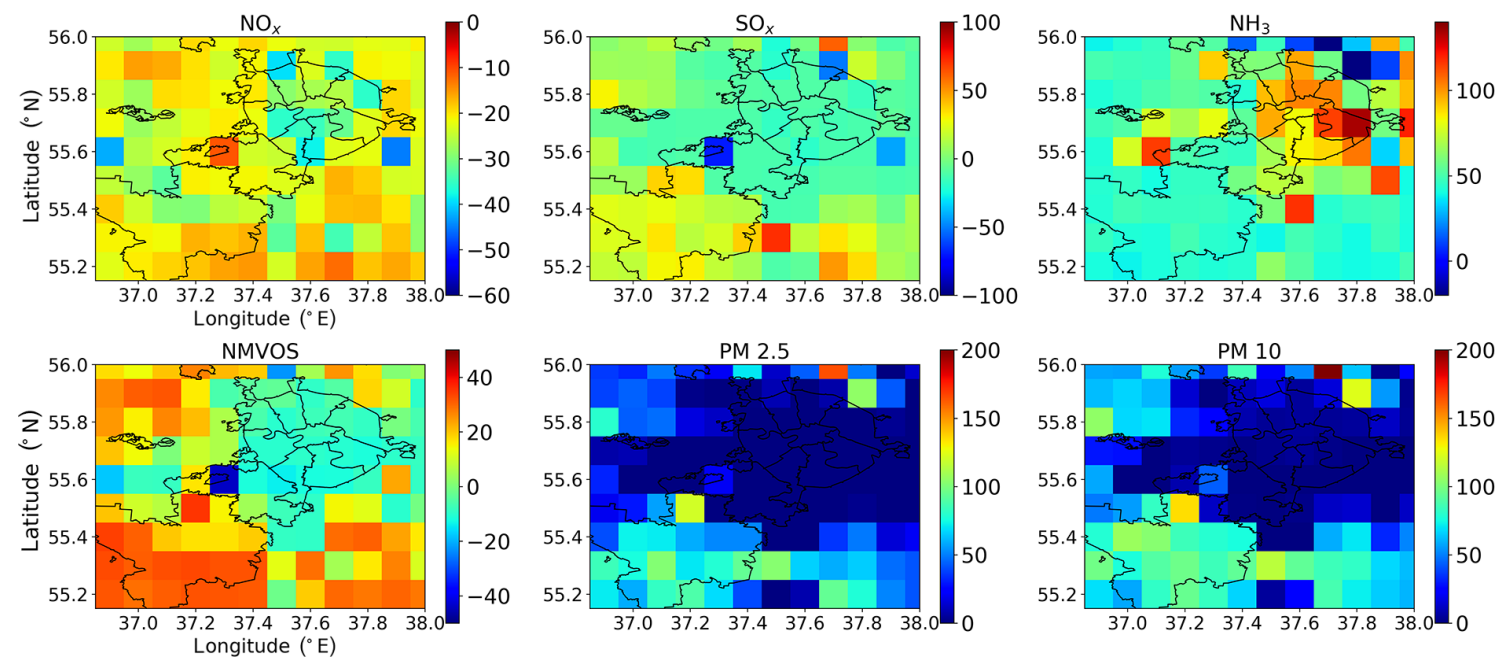

Figure 10. Ratio of emissions of gases and particle matter averaged over the 2011-2016 period to the emissions averaged over the 2003-2009 period, in percentages. EMEP dataset (http://www.ceip.at/new_emep-grid/01_grid_data, last access: 1 August 2019; EMEP/CEIP, 2019).
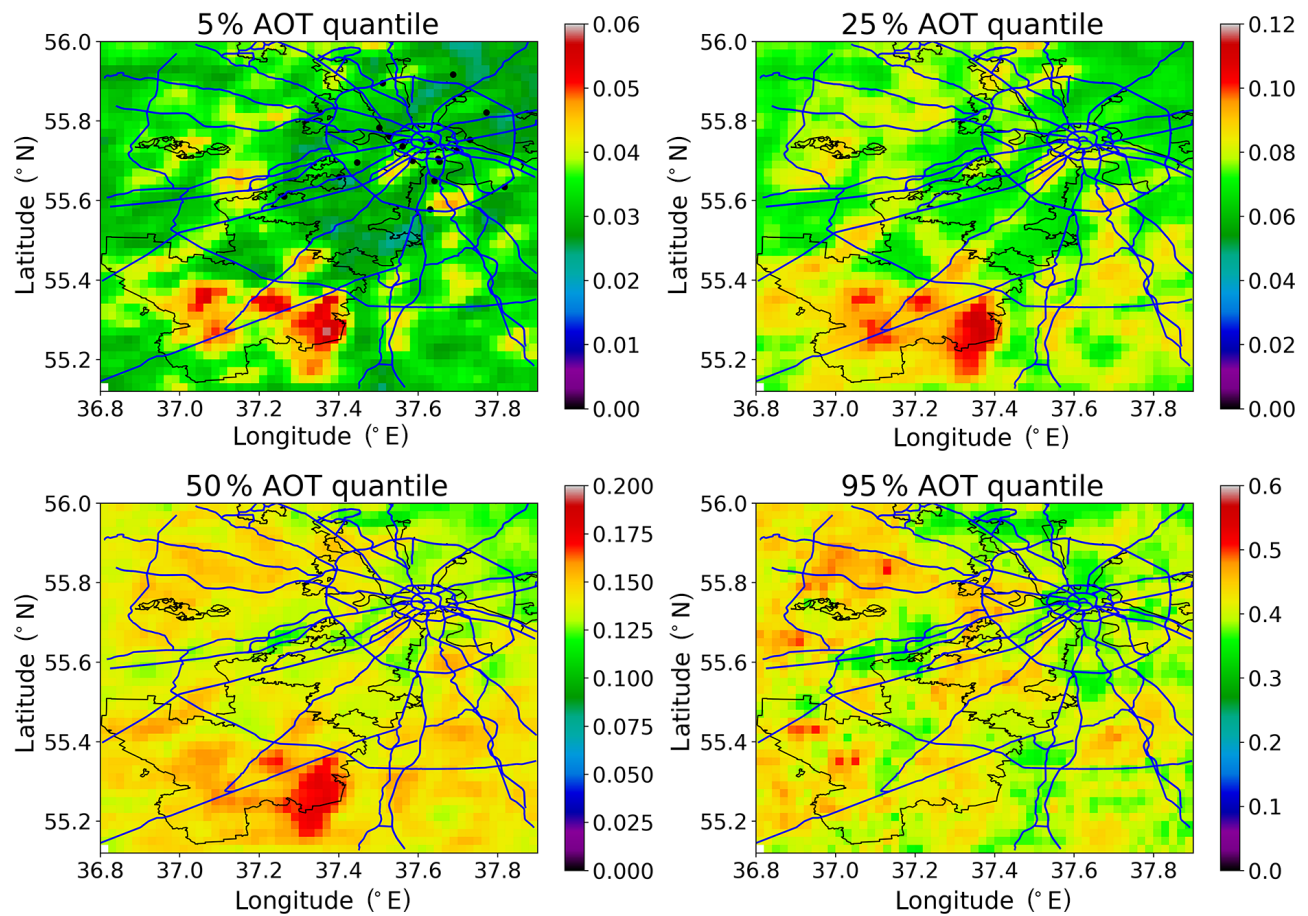

Figure 11. Quantiles' (5\%, 25\%, 50\%, $95 \%$ ) AOT at $0.47 \mu \mathrm{m}$ over the Moscow megacity, 2001-2017, Aqua and Terra datasets together. Black points in the upper left map are thermal power plants according to the "System Operator of the United Power System" data (https: //www.so-ups.ru, last access: 20 December 2019). Blue lines are the main highways (data: OpenStreetMap - https://www.openstreetmap.org, last access: 20 December 2019).

Moscow megacity. Median AOT values according to the Terra dataset are slightly higher (by 0.01-0.02) than the Aqua dataset. The discrepancies in $95 \%$ quantile AOT estimates according to these datasets link with the different samples of Terra and Aqua observations.

We also estimated the AOT difference depending on the distance from the city centre. Frequency distribution of AOT at $0.47 \mu \mathrm{m}$ differences averaged over the two areas, bounded by circles with a radius of 15 and $50 \mathrm{~km}$ centred in the Moscow city centre, consisted of $33 \%$ of cases in the range of $[-0.02,0]$ and $60 \%$ of cases in the range of $[0,0.02]$. This finding is also consistent with ground-based data. 
Table 2. Mean and maximum of AOT quantiles (5\%, 25\%, 50\%, $95 \%$ ) over the "Old" Moscow and "New” Moscow territories, $2001-2017$.

\begin{tabular}{|c|c|c|c|c|}
\hline \multirow[t]{2}{*}{ Quantile } & \multicolumn{2}{|c|}{ "Old" Moscow } & \multicolumn{2}{|c|}{ "New" Moscow } \\
\hline & $\begin{array}{l}\text { AOT at } 0.47 \mu \mathrm{m} \\
(\text { mean } / \max )\end{array}$ & $\begin{array}{l}\text { AOT at } 0.55 \mu \mathrm{m} \\
(\text { mean/max })\end{array}$ & $\begin{array}{l}\text { AOT at } 0.47 \mu \mathrm{m} \\
\quad(\text { mean } / \max )\end{array}$ & $\begin{array}{l}\text { AOT at } 0.55 \mu \mathrm{m} \\
(\mathrm{mean} / \mathrm{max})\end{array}$ \\
\hline \multicolumn{5}{|l|}{ Aqua } \\
\hline $5 \%$ & $0.03 / 0.06$ & $0.02 / 0.04$ & $0.04 / 0.06$ & $0.02 / 0.04$ \\
\hline $25 \%$ & $0.07 / 0.1$ & $0.05 / 0.07$ & $0.08 / 0.11$ & $0.05 / 0.08$ \\
\hline $50 \%$ & $0.12 / 0.15$ & $0.08 / 0.11$ & $0.13 / 0.17$ & $0.09 / 0.12$ \\
\hline $95 \%$ & $0.34 / 0.50$ & $0.24 / 0.36$ & $0.33 / 0.52$ & $0.23 / 0.37$ \\
\hline \multicolumn{5}{|l|}{ Terra } \\
\hline $5 \%$ & $0.03 / 0.04$ & $0.02 / 0.03$ & $0.04 / 0.06$ & $0.02 / 0.04$ \\
\hline $25 \%$ & $0.07 / 0.09$ & $0.05 / 0.06$ & $0.08 / 0.12$ & $0.06 / 0.08$ \\
\hline $50 \%$ & $0.14 / 0.17$ & $0.1 / 0.11$ & $0.15 / 0.19$ & $0.1 / 0.13$ \\
\hline $95 \%$ & $0.42 / 0.52$ & $0.3 / 0.37$ & $0.45 / 0.55$ & $0.32 / 0.39$ \\
\hline \multicolumn{5}{|c|}{ Aqua and Terra } \\
\hline $5 \%$ & $0.03 / 0.05$ & $0.02 / 0.03$ & $0.03 / 0.06$ & $0.02 / 0.04$ \\
\hline $25 \%$ & $0.07 / 0.09$ & $0.05 / 0.06$ & $0.08 / 0.11$ & $0.05 / 0.08$ \\
\hline $50 \%$ & $0.13 / 0.16$ & $0.09 / 0.11$ & $0.14 / 0.18$ & $0.1 / 0.12$ \\
\hline $95 \%$ & $0.39 / 0.48$ & $0.28 / 0.34$ & $0.41 / 0.51$ & $0.29 / 0.36$ \\
\hline
\end{tabular}

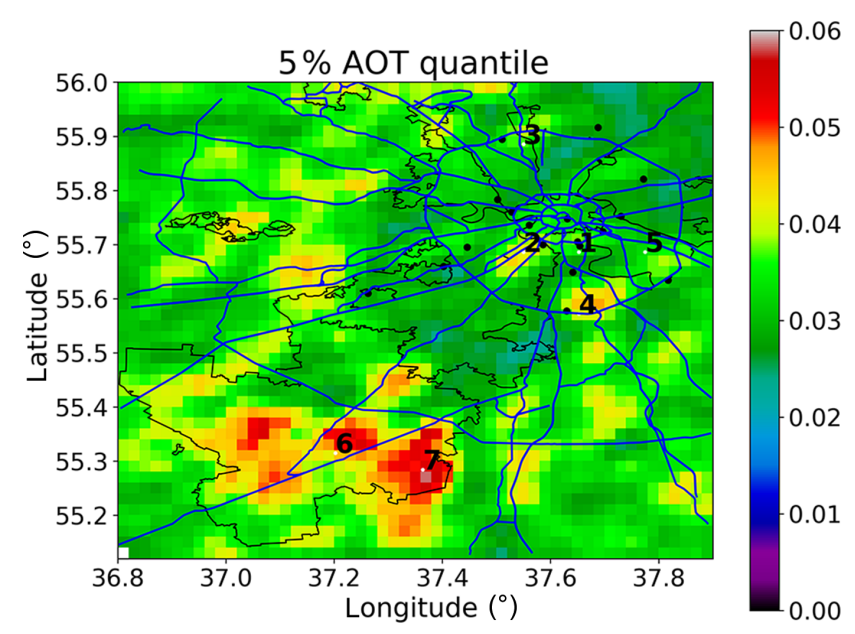

Figure 12. The $5 \%$ quantile of AOT at $0.47 \mu \mathrm{m}, 2001-2017$. Points on map: 1, 3, 5: industrial zones with building construction area; 2 , 4: highways; 6, 7: farmlands.

\section{Discussion and conclusions}

The MAIAC AOT (MODIS product MCD19A2) was used for the analysis of the urban aerosol pollution and its dynamics over the Moscow megacity. MAIAC AOT was validated against two AERONET sites located near the centre of Moscow (Moscow_MSU_MO) and in the suburban region (Zvenigorod). The validation showed a good overall agreement between the ground-based and satellite data, though MAIAC underestimated AOT by $0.05-0.1$ for typical condi- tions $($ AOT $<1)$. Statistical analysis showed a similar MAIAC AOT performance for the two sites, i.e. $\mathrm{RMSE}=0.1$, MAE $=0.07$, BIAS $=-0.06$ for Moscow_MSU_MO and $\mathrm{RMSE}=0.08, \mathrm{MAE}=0.06, \mathrm{BIAS}=-0.04$ for Zvenigorod. The obtained estimates are consistent with the global MAIAC AOT validation over the land, e.g. $\mathrm{RMSE}=0.06-$ 0.08 and BIAS $=-0.01-0.03$ over the North and South American continents (Lyapustin et al., 2018).

On average, the MAIAC AOT product reproduces the absolute AOT values and the AOT decrease since 2012 observed in the AERONET data and shows a robust performance in urban environments with higher land surface reflectance. These results are in agreement with other studies, such as Sever et al. (2017), which showed that the pollution from the industrial zone could be identified with MAIAC AOT data even over bright semi-deserts of the Dead Sea area.

In high-AOT conditions (AOT $>1$ ) observed during the Moscow forest and peat fires of 2010, MAIAC showed an overestimation of AOT. This result is in contrast to the typical biomass burning conditions when MAIAC usually underestimates AOT by $\sim 10 \%-20 \%$ (e.g. see Lyapustin et al., 2018). The MAIAC C6 algorithm lacks a specialized smoke aerosol model with higher absorption and keeps using the regional background aerosol model in cases of detected smoke, which usually has a higher absorption (Dubovik et al., 2002), in particular for the fresh smoke. Atypically, the Moscow 2010 smoke was mostly generated by the slow smouldering peat burning which produces a relatively large particle size and a low absorption (Chubarova et al., 2012; Sayer et al., 2014). 
The combination of these properties of smoke particles not accounted for in the MAIAC algorithm may have resulted in the observed AOT overestimation. In general, we found that MAIAC smoke detection was a good indicator of forest and peat fires in the Moscow region. The ability of the MAIAC algorithm to confidently capture both fresh and transported smoke in the aerosol-type parameter has also been confirmed in Veselovskii et al. (2015).

To evaluate the urban aerosol effect, we analysed the spatial difference between simultaneously measured AOT at Moscow_MSU_MO and at Zvenigorod $(\triangle \mathrm{AOT}=\mathrm{AOT}$ (MOSCOW_MO_MSU) - AOT (ZVENIGOROD)), which was produced from both the AERONET and MAIAC datasets. AERONET measurements showed that the annual median $\triangle$ AOT varied within -0.002 to +0.03 , with a statistically significant positive bias for most years and an average difference of $\sim 0.02$. A similar result was reported for the urban conditions of Warsaw (Zawadzka et al., 2013), where $\triangle$ AOT between Warsaw and Belsk was estimated as $\sim 0.02$ (at $500 \mathrm{~nm}$ ) and 0.03 (at $550 \mathrm{~nm}$ ) according to the AERONET and standard MODIS aerosol products, respectively. According to Fig. 8, MAIAC also showed a positive $\triangle \mathrm{AOT} \sim 0.01$ between Moscow and Zvenigorod for all years except 2011 (in 2017 both AERONET and MAIAC showed a negative difference), but it was not statistically significant due to higher noise in the MAIAC retrievals compared to the direct AERONET measurements. In comparison, a similar assessment using the standard MODIS aerosol algorithm showed $\triangle \mathrm{AOT}=0.03$ (Chubarova et al., 2011b). Note that similar analysis between the centre of Berlin and its suburbs resulted in a much higher $\triangle \mathrm{AOT}$ of 0.08 ( $\mathrm{Li}$ et al., 2018). Such a difference seems to be too high and could be explained by the urban bias of the standard MODIS collection MYD04_3K (3 km AOT product) caused by the brighter underlying surface. In a previous study (Remer et al., 2013) the MODIS $3 \mathrm{~km}$ product based on the Dark Target algorithm was shown to have aerosol gradients of better resolution than those obtained from the MODIS $10 \mathrm{~km}$ product. However, this product tends to show more noise, especially in urban areas (Munchak et al., 2013). Global validation of the MODIS $3 \mathrm{~km}$ product exhibits a mean positive bias of 0.06 for Terra and 0.03 for Aqua (Gupta et al., 2018). It was also revealed that the MODIS $3 \mathrm{~km}$ product overestimates AOT values for the Moscow region (Zhdanova and Chubarova, 2018). In a recent paper (Jin et al., 2019) an improved AOD retrieval method for $500 \mathrm{~m}$ MODIS data has been proposed, which is based on an extended surface reflectance estimation scheme and dynamic aerosol models derived from ground-based sun-photometric observations. Its validation with AERONET data showed good results, $R=$ 0.89 , while our testing of the MAIAC aerosol product over the urban territory of Moscow has revealed a correlation coefficient $R$ of 0.97 .

Both AERONET and MAIAC show the decreasing trend of the urban aerosol effect ( $\triangle$ AOT) since 2012, which is con- sistent with the increase in pollutant emissions over Zvenigorod and their decrease over Moscow during the last years according to the EMEP archive (see Fig. 10).

The analysis of the spatial distribution of MAIAC AOT at $0.47 \mu \mathrm{m}$ shows higher values over the highways and main roads, building construction areas, and over the territory of "New" Moscow at the 5\%,25\%, and 50\% quantile levels with $0.05-0.06$ differences against lowest values. The largest local difference in AOT is observed in the clean conditions at the $5 \%$ quantile. Hence, our results confirm the statement in A. A. Chudnovsky et al. (2013) that "low pollution days require higher resolution aerosol retrievals to describe spatial AOT heterogeneity in urban environment", which resulted from MAIAC-based study over the Boston area. The higher AOT over the territory of "New" Moscow can be explained by the increased aerosol precursor emissions from intensive construction and agricultural activities. The difference between the maximum and mean AOT values for different quantiles, except the $95 \%$ quantile, within the Moscow region is about $0.02-0.04$, which can be attributed to the local aerosol effects.

Thus, the application of the new MAIAC algorithm provides a reliable instrument for assessing the spatial distribution of aerosol pollution and allows us to evaluate the level of the local aerosol effect of about $0.02-0.04$ in the visible spectral range over the Moscow megacity as well as its temporal dynamics, which has a tendency of AOT decreasing over the "Old" Moscow and increasing over the "New" Moscow territories.

In this research we have verified the MAIAC algorithm data against ground-based data and obtained spatial and temporal variability of AOT MAIAC retrievals over the Moscow region for evaluating aerosol pollution. Future studies focused on the influence of different meteorological conditions on AOT MAIAC retrievals will be valuable for detection events of the extreme urban aerosol pollution and further MAIAC product validation.

Data availability. The MODIS product data - MCD19A2 Collection 6 (MAIAC aerosol product) and MCD12C1 Collection 6 products - were obtained from https://search.earthdata.nasa.gov/search (last access: 1 August 2019). The grid archive of aerosol precursor gas emissions and particulate matter concentrations is available at http://www.ceip.at/new_emep-grid/01_grid_data (last access: 1 August 2019; EMEP/CEIP, 2019). The AERONET version 3 data at the Moscow_MO_MSU and Zvenigorod sites are available from the AERONET data repository at https://aeronet.gsfc.nasa.gov (last access: 1 August 2019).

Author contributions. EYZ and NYC designed the study and wrote the paper with essential contributions from AIL. EYZ was responsible for data collection and visualization. Data analysis was performed by EYZ and NYC. 
Competing interests. The authors declare that they have no conflict of interest.

Acknowledgements. We thank the RAS Zvenigorod Scientific Station staff for their efforts in establishing and maintaining the Zvenigorod AERONET site.

Financial support. This research has been supported by the Russian Science Foundation (grant no. 18-17-00149). The work of Alexei I. Lyapustin was funded by the NASA Science of Terra, Aqua, and SNPP programs (17-TASNPP17-0116; solicitation NNH17ZDA001NTASNPP).

Review statement. This paper was edited by Alexander Kokhanovsky and reviewed by three anonymous referees.

\section{References}

Beloconi, A., Chrysoulakis, N., Lyapustin, A., Utzinger, J., and Vounatsou, P.: Bayesian geostatistical modelling of $\mathrm{PM}_{10}$ and $\mathrm{PM}_{2.5}$ surface level concentrations in Europe using highresolution satellite-derived products, Environ. Int., 121, 57-70, https://doi.org/10.1016/j.envint.2018.08.041, 2018.

Bovchaliuk, A., Milinevsky, G., Danylevsky, V., Goloub, P., Dubovik, O., Holdak, A., Ducos, F., and Sosonkin, M.: Variability of aerosol properties over Eastern Europe observed from ground and satellites in the period from 2003 to 2011, Atmos. Chem. Phys., 13, 6587-6602, https://doi.org/10.5194/acp13-6587-2013, 2013.

Chernogaeva, G. M., Zhadanovskaya, E. A., and Malevanov, Y. A.: Pollution sources and air quality in the Moscow Region, Izvestiya Rossiiskoi akademii nauk. Seriya geograficheskaya, 2, 109-116, https://doi.org/10.31857/S2587556620192109-116, 2019.

Chubarova, N., Nezval', Ye., Sviridenkov, I., Smirnov, A., and Slutsker, I.: Smoke aerosol and its radiative effects during extreme fire event over Central Russia in summer 2010, Atmos. Meas. Tech., 5, 557-568, https://doi.org/10.5194/amt-5557-2012, 2012.

Chubarova, N. Y.: Seasonal distribution of aerosol properties over Europe and their impact on UV irradiance, Atmos. Meas. Tech., 2, 593-608, https://doi.org/10.5194/amt-2-593-2009, 2009.

Chubarova, N. Y., Smirnov, A., and Holben, B.: AEROSOL PROPERTIES IN MOSCOW ACCORDING TO 10 YEARS OF AERONET MEASUREMENTS AT THE METEOROLOGICAL OBSERVATORY OF MOSCOW STATE UNIVERSITY, Geography, Environment, Sustainability, 4, 19-32, https://doi.org/10.24057/2071-9388-2011-4-1-19-32, 2011a.

Chubarova, N. Y., Sviridenkov, M. A., Smirnov, A., and Holben, B. N.: Assessments of urban aerosol pollution in Moscow and its radiative effects, Atmos. Meas. Tech., 4, 367-378, https://doi.org/10.5194/amt-4-367-2011, 2011 b.

Chubarova, N. Y., Poliukhov, A. A., and Gorlova, I. D.: Long-term variability of aerosol optical thickness in Eastern Europe over 2001-2014 according to the measurements at the Moscow MSU
MO AERONET site with additional cloud and $\mathrm{NO}_{2}$ correction, Atmos. Meas. Tech., 9, 313-334, https://doi.org/10.5194/amt-9313-2016, 2016.

Chudnovsky, A., Tang, C., Lyapustin, A., Wang, Y., Schwartz, J., and Koutrakis, P.: A critical assessment of high-resolution aerosol optical depth retrievals for fine particulate matter predictions, Atmos. Chem. Phys., 13, 10907-10917, https://doi.org/10.5194/acp-13-10907-2013, 2013.

Chudnovsky, A. A., Lee, H. J., Kostinski, A., Kotlov, T., and Koutrakis, P.: Prediction of daily fine particulate matter concentrations using aerosol optical depth retrievals from the Geostationary Operational Environmental Satellite (GOES), J. Air Waste Manage., 62, 1022-1031, https://doi.org/10.1080/10962247.2012.695321, 2012.

Chudnovsky, A. A., Kostinski, A., Lyapustin, A., and Koutrakis, P.: Spatial scales of pollution from variable resolution satellite imaging, Environ. Pollut., 172, 131-138, https://doi.org/10.1016/j.envpol.2012.08.016, 2013.

Della Ceca, L. S., García Ferreyra, M. F., Lyapustin, A., Chudnovsky, A., Otero, L., Carreras, H., and Barnaba, F.: Satellitebased view of the aerosol spatial and temporal variability in the Córdoba region (Argentina) using over ten years of high-resolution data, ISPRS J. Photogramm., 145, 250-267, https://doi.org/10.1016/j.isprsjprs.2018.08.016, 2018.

Dubovik, O., Holben, B., Eck, T. F., Smirnov, A., Kaufman, Y. J., King, M. D., Tanré, D., and Slutsker, I.: Variability of Absorption and Optical Properties of Key Aerosol Types Observed in Worldwide Locations, J. Atmos. Sci., 59, 590-608, https://doi.org/10.1175/15200469(2002)059<0590:VOAAOP>2.0.CO;2, 2002.

EMEP/CEIP: Grid emissions in $0.1^{\circ} \times 0.1^{\circ}$ long-lat resolution, available at: https://www.ceip.at/new_emep-grid/01_grid_data, last access: 1 August 2019.

Emili, E., Lyapustin, A., Wang, Y., Popp, C., Korkin, S., Zebisch, M., Wunderle, S., and Petitta, M.: High spatial resolution aerosol retrieval with MAIAC: Application to mountain regions, J. Geophys. Res.-Atmos., 116, D23211, https://doi.org/10.1029/2011JD016297, 2011.

Giles, D. M., Sinyuk, A., Sorokin, M. G., Schafer, J. S., Smirnov, A., Slutsker, I., Eck, T. F., Holben, B. N., Lewis, J. R., Campbell, J. R., Welton, E. J., Korkin, S. V., and Lyapustin, A. I.: Advancements in the Aerosol Robotic Network (AERONET) Version 3 database - automated near-real-time quality control algorithm with improved cloud screening for Sun photometer aerosol optical depth (AOD) measurements, Atmos. Meas. Tech., 12, 169209, https://doi.org/10.5194/amt-12-169-2019, 2019.

Gupta, P., Remer, L. A., Levy, R. C., and Mattoo, S.: Validation of MODIS $3 \mathrm{~km}$ land aerosol optical depth from NASA's EOS Terra and Aqua missions, Atmos. Meas. Tech., 11, 3145-3159, https://doi.org/10.5194/amt-11-3145-2018, 2018.

Han, W., Tong, L., Chen, Y., Li, R., Yan, B., and Liu, X.: Estimation of High-Resolution Daily Ground-Level $\mathrm{PM}_{2.5}$ Concentration in Beijing 2013-2017 Using 1 km MAIAC AOT Data, Appl. Sci., 8, 2624, https://doi.org/10.3390/app8122624, 2018.

Hoff, R. M. and Christopher, S. A.: Remote Sensing of Particulate Pollution from Space: Have We Reached the Promised Land?, J. Air Waste Manage., 59, 645-675, https://doi.org/10.3155/10473289.59.6.645, 2009. 
Holben, B. N., Eck, T. F., Slutsker, I., Tanré, D., Buis, J. P., Setzer, A., Vermote, E., Reagan, J. A., Kaufman, Y. J., Nakajima, T., Lavenu, F., Jankowiak, I., and Smirnov, A.: AERONET - A Federated Instrument Network and Data Archive for Aerosol Characterization, Remote Sens. Environ., 66, 1-16, https://doi.org/10.1016/S0034-4257(98)00031-5, 1998.

Hsu, N. C., Jeong, M.-J., Bettenhausen, C., Sayer, A. M., Hansell, R., Seftor, C. S., Huang, J., and Tsay, S. -C.: Enhanced Deep Blue aerosol retrieval algorithm: The second generation, J. Geophys. Res.-Atmos., 118, 9296-9315, https://doi.org/10.1002/jgrd.50712, 2013.

Hu, X., Waller, L. A., Lyapustin, A., Wang, Y., Al-Hamdan, M. Z., Crosson, W. L., Estes, M. G., Estes, S. M., Quattrochi, D. A., Puttaswamy, S. J., and Liu, Y.: Estimating ground-level $\mathrm{PM}_{2.5}$ concentrations in the Southeastern United States using MAIAC AOD retrievals and a two-stage model, Remote Sens. Environ., 140, 220-232, https://doi.org/10.1016/j.rse.2013.08.032, 2014.

IPCC: Climate Change 2013: The Physical Science Basis. Contribution of Working Group I to the Fifth Assessment Report of the Intergovernmental Panel on Climate Change, edited by: Stocker, T. F., Qin, D., Plattner, G.-K., Tignor, M., Allen, S. K., Boschung, J., Nauels, A., Xia, Y., Bex, V., and Midgley, P. M., Cambridge University Press, Cambridge, UK and New York, NY, USA, 1535 pp., https://doi.org/10.1017/CBO9781107415324, 2013.

Jackson, J. M., Liu, H., Laszlo, I., Kondragunta, S., Remer, L. A., Huang, J., and Huang, H.-C.: Suomi-NPP VIIRS aerosol algorithms and data products, J. Geophys. Res.-Atmos., 118, 1267312689, https://doi.org/10.1002/2013JD020449, 2013.

Jethva, H., Torres, O., and Yoshida, Y.: Accuracy assessment of MODIS land aerosol optical thickness algorithms using AERONET measurements over North America, Atmos. Meas. Tech., 12, 4291-4307, https://doi.org/10.5194/amt-124291-2019, 2019.

Jin, S., Ma, Y., Zhang, M., Gong, W., Dubovik, O., Liu, B., Shi, Y., and Yang, C.: Retrieval of $500 \mathrm{~m}$ Aerosol Optical Depths from MODIS Measurements over Urban Surfaces under Heavy Aerosol Loading Conditions in Winter, Remote Sensing, 11, 2218, https://doi.org/10.3390/rs11192218, 2019.

Kaufman, Y. J.: Satellite Observations of Natural and Anthropogenic Aerosol Effects on Clouds and Climate, Space Sci Rev, 125, 139-147, https://doi.org/10.1007/s11214-006-9052-7, 2006.

Kaufman, Y. J., Holben, B. N., Tanré, D., Slutsker, I., Smirnov, A., and Eck, T. F.: Will aerosol measurements from Terra and Aqua Polar Orbiting satellites represent the daily aerosol abundance and properties?, Geophys. Res. Lett., 27, 3861-3864, https://doi.org/10.1029/2000GL011968, 2000.

Kaufman, Y. J., Tanré, D., and Boucher, O.: A satellite view of aerosols in the climate system, Nature, 419, 215-223, https://doi.org/10.1038/nature01091, 2002.

Kaufman, Y. J., Boucher, O., Tanré, D., Chin, M., Remer, L. A., and Takemura, T.: Aerosol anthropogenic component estimated from satellite data, Geophys. Res. Lett., 32, L17804, https://doi.org/10.1029/2005GL023125, 2005.

Kislov, A. V. (Ed.): Moscow Climate under Global Warming, Publishing House of Moscow University, Moscow, 288 pp., 2017 (in Russian).

Kloog, I., Sorek-Hamer, M., Lyapustin, A., Coull, B., Wang, Y., Just, A. C., Schwartz, J., and Broday, D. M.: Estimating daily
$\mathrm{PM}_{2.5}$ and $\mathrm{PM}_{10}$ across the complex geo-climate region of Israel using MAIAC satellite-based AOD data, Atmos. Environ., 122, 409-416, https://doi.org/10.1016/j.atmosenv.2015.10.004, 2015.

Koelemeijer, R. B. A., Homan, C. D., and Matthijsen, J.: Comparison of spatial and temporal variations of aerosol optical thickness and particulate matter over Europe, Atmos. Environ., 40, 53045315, https://doi.org/10.1016/j.atmosenv.2006.04.044, 2006.

Kopeikin, V. M., Emilenko, A. S., Isakov, A. A., Loskutova, O. V., and Ponomareva, T. Ya.: Variability of Soot and Fine Aerosol in the Moscow Region in 2014-2016, Atmos. Ocean. Opt., 31, 243-249, https://doi.org/10.1134/S1024856018030089, 2018.

Kulbachevski, A. O.: Report on the State of the Environment in Moscow in 2017, The Department for nature use and environment protection of Moscow Government, 358 pp., available at: http://www.dpioos.ru/eco/ru/report_result/o_448938 (last access: 13 August 2019), 2018 (in Russian).

Levy, R. C., Mattoo, S., Munchak, L. A., Remer, L. A., Sayer, A. M., Patadia, F., and Hsu, N. C.: The Collection 6 MODIS aerosol products over land and ocean, Atmos. Meas. Tech., 6, 29893034, https://doi.org/10.5194/amt-6-2989-2013, 2013.

Li, H., Meier, F., Lee, X., Chakraborty, T., Liu, J., Schaap, M., and Sodoudi, S.: Interaction between urban heat island and urban pollution island during summer in Berlin, Sci. Total Environ., 636, 818-828, https://doi.org/10.1016/j.scitotenv.2018.04.254, 2018.

Liang, F., Xiao, Q., Wang, Y., Lyapustin, A., Li, G., Gu, D., Pan, X., and Liu, Y.: MAIAC-based long-term spatiotemporal trends of $\mathrm{PM}_{2.5}$ in Beijing, China, Sci. Total Environ., 616-617, 15891598, https://doi.org/10.1016/j.scitotenv.2017.10.155, 2018.

Liu, H., Remer, L. A., Huang, J., Huang, H.-C., Kondragunta, S., Laszlo, I., Oo, M., and Jackson, J. M.: Preliminary evaluation of S-NPP VIIRS aerosol optical thickness, J. Geophys. Res.-Atmos., 119, 3942-3962, https://doi.org/10.1002/2013JD020360, 2014.

Lyapustin, A., Korkin, S., Wang, Y., Quayle, B., and Laszlo, I.: Discrimination of biomass burning smoke and clouds in MAIAC algorithm, Atmos. Chem. Phys., 12, 9679-9686, https://doi.org/10.5194/acp-12-9679-2012, 2012.

Lyapustin, A., Wang, Y., Korkin, S., and Huang, D.: MODIS Collection 6 MAIAC algorithm, Atmos. Meas. Tech., 11, 5741-5765, https://doi.org/10.5194/amt-11-5741-2018, 2018.

Martins, V. S., Lyapustin, A., de Carvalho, L. A. S., Barbosa, C. C. F., and Novo, E. M. L. M.: Validation of high-resolution MAIAC aerosol product over South America, J. Geophys. Res.-Atmos., 122, 7537-7559, https://doi.org/10.1002/2016JD026301, 2017.

Mhawish, A., Banerjee, T., Sorek-Hamer, M., Lyapustin, A., Broday, D. M., and Chatfield, R.: Comparison and evaluation of MODIS Multi-angle Implementation of Atmospheric Correction (MAIAC) aerosol product over South Asia, Remote Sens. Environ., 224, 12-28, https://doi.org/10.1016/j.rse.2019.01.033, 2019.

Munchak, L. A., Levy, R. C., Mattoo, S., Remer, L. A., Holben, B. N., Schafer, J. S., Hostetler, C. A., and Ferrare, R. A.: MODIS $3 \mathrm{~km}$ aerosol product: applications over land in an urban/suburban region, Atmos. Meas. Tech., 6, 1747-1759, https://doi.org/10.5194/amt-6-1747-2013, 2013.

O’Neill, N., Eck, T. F., Smirnov, A., Holben, B. N., and Thulasiraman, S.: Spectral discrimination of coarse and fine mode optical depth, J. Geophys. Res., 108, 4559-4573, https://doi.org/10.1029/2002JD002975, 2003. 
Putaud, J. P., Cavalli, F., Martins dos Santos, S., and Dell'Acqua, A.: Long-term trends in aerosol optical characteristics in the Po Valley, Italy, Atmos. Chem. Phys., 14, 9129-9136, https://doi.org/10.5194/acp-14-9129-2014, 2014.

Remer, L. A., Mattoo, S., Levy, R. C., and Munchak, L. A.: MODIS $3 \mathrm{~km}$ aerosol product: algorithm and global perspective, Atmos. Meas. Tech., 6, 1829-1844, https://doi.org/10.5194/amt-6-18292013, 2013.

Sayer, A. M., Hsu, N. C., Eck, T. F., Smirnov, A., and Holben, B. N.: AERONET-based models of smoke-dominated aerosol near source regions and transported over oceans, and implications for satellite retrievals of aerosol optical depth, Atmos. Chem. Phys., 14, 11493-11523, https://doi.org/10.5194/acp-14-114932014, 2014.

Schaap, M., Timmermans, R. M. A., Koelemeijer, R. B. A., de Leeuw, G., and Builtjes, P. J. H.: Evaluation of MODIS aerosol optical thickness over Europe using sun photometer observations, Atmos. Environ., 42, 2187-2197, https://doi.org/10.1016/j.atmosenv.2007.11.044, 2008.

Sever, L., Alpert, P., Lyapustin, A., Wang, Y., and Chudnovsky, A.: An example of aerosol pattern variability over bright surface using high resolution MODIS MAIAC: The eastern and western areas of the Dead Sea and environs, Atmos. Environ., 165, 359369, https://doi.org/10.1016/j.atmosenv.2017.06.047, 2017.

Sitnov, S. A., Mokhov, I. I., and Gorchakov, G. I.: The link between smoke blanketing of European Russia in summer 2016, Siberian wildfires and anomalies of large-scale atmospheric circulation, Dokl. Earth Sci., 472, 190-195, https://doi.org/10.1134/S1028334X17020052, 2017.

van Donkelaar, A., Martin, R. V., Brauer, M., and Boys, B. L.: Use of Satellite Observations for Long-Term Exposure Assessment of Global Concentrations of Fine Particulate Matter, Environ. Health Persp., 123, 135-143, https://doi.org/10.1289/ehp.1408646, 2015.
Veselovskii, I., Whiteman, D. N., Korenskiy, M., Suvorina, A., Kolgotin, A., Lyapustin, A., Wang, Y., Chin, M., Bian, H., Kucsera, T. L., Pérez-Ramírez, D., and Holben, B.: Characterization of forest fire smoke event near Washington, DC in summer 2013 with multi-wavelength lidar, Atmos. Chem. Phys., 15, 16471660, https://doi.org/10.5194/acp-15-1647-2015, 2015.

Wang, J. and Christopher, S. A.: Intercomparison between satellitederived aerosol optical thickness and $\mathrm{PM}_{2.5}$ mass: Implications for air quality studies, Geophys. Res. Lett., 30, 2095, https://doi.org/10.1029/2003GL018174, 2003.

Xiao, Q., Wang, Y., Chang, H. H., Meng, X., Geng, G., Lyapustin, A., and Liu, Y.: Full-coverage high-resolution daily $\mathrm{PM}_{2.5}$ estimation using MAIAC AOD in the Yangtze River Delta of China, Remote Sens. Environ., 199, 437-446, https://doi.org/10.1016/j.rse.2017.07.023, 2017.

Zawadzka, O., Markowicz, K. M., Pietruczuk, A., Zielinski, T., and Jaroslawski, J.: Impact of urban pollution emitted in Warsaw on aerosol properties, Atmos. Environ., 69, 15-28, https://doi.org/10.1016/j.atmosenv.2012.11.065, 2013.

Zhdanova, E. Yu. and Chubarova, N. Ye.: Spatial variability of aerosol optical thickness on the territory of Moscow and Moscow Region by satellite and ground based data, Sovremennye problemy distantsionnogo zondirovaniya Zemli iz kosmosa, 15, 236-248, https://doi.org/10.21046/2070-7401-201815-7-236-248, 2018. 